\title{
PELATIHAN PEMANFAATAN LIMBAH KANTONG PLASTIK MENJADI ANEKA PRODUK KERAJINAN BAGI IBU-IBU PPK KELURAHAN NUSUKAN KECAMATAN BANJARSARI SURAKARTA
}

\author{
Murni Sulistyowati ${ }^{1}$, Nunuk Herawati ${ }^{*}$ \\ STIE Adi Unggul Bhirawa Surakarta \\ E-mail : * murnisulistyowati19@gmail.com
}

\begin{abstract}
ABSTRAK
Pengabdian Kepada Masyarakat tentang pelatihan pemanfaatan limbah kantong plastik menjadi aneka produk kerajinan ini dilaksanakan di Kelurahan Nusukan Kecamatan Banjarsari Kodya Surakarta dengan sasaran kelompok pengrajin dan Ibu-ibu PKK. Tujuan kegiatan pengabdian inii adalah memberikan penyuluhan tentang bahaya limbah plastik bagi lingkungan dan memberikan pelatihan tentang pemanfaatan limbah plastik dengan cara re-use (penggunaan kembali) yaitu membuat/mengubah limbah plastik khususnya tas kresek menjadi aneka produk kerajinan yang bernilai seni dan bernilai ekonomis dengan teknik merajut (cronchet) serta memberikan pelatihan tentang teknik pengemasan dan pemasaran produk kerajinan hasil pemanfaatan limbah kantong plastik. Metode yang digunakan dalam kegiatan Pengabdian ini adalah metode ceramah tentang bahaya limbah plastik serta pelatihan dengan presentasi, peragaan dan pembagian alat serta bahan agar para peserta yaitu kelompok pengrajin dan Ibu-ibu PKK dapat langsung terlibat berlatih dan berkraeasi memanfaatkan ketrampilannya membuat aneka produk kerajinan dengan memanfaatkan tas kresek sebagai plastik. Kegiatan pengabdian kepada masyarakat ini diharapkan dapat mencapai luaran berupa aneka produk kerajinan hasil re-use tas kresek (limbah plastik) yang bernilai seni dan bernilai ekonomis, layak jual sehingga dapat meningkatkan pendapatan keluarga dan berkembang menjadi usaha yang menjanjikan pada masa mendatang. Target setelah dilaksanakan pelatihan cukup menggembirakan $60 \%$ tujuan pelatihan tercapai dan sisanya perlu ditindak lanjuti dengan pendampingan untuk Pengabdian Kepada Masyarakat berikutnya.
\end{abstract}

Kata kunci : Limbah plastik, Kelompok pengrajin dan Ibu-ibu PKK, pelatihan dan pendampingan.

\section{PENDAHULUAN}

Kota Surakarta yang memiliki semboyan mulat sarira angrasa wanidan slogan umum berseri (akronim bersih sehat rapi indah) serta slogan pariwisata The spirit of Java ini memiliki luas wilayah $44 \mathrm{~km}^{2}$ terdiri dari 5 kecamatan dan 51 kelurahan dengan jumlah penduduk mencapai 503.421 jiwa (sumber: wikipedia th.2010) dan tingkat kepadatan penduduk tertinggi di Jawa Tengah yaitu 11.370 jiwa/km². ( kepadatan Jawa Tengah hanya 992 jiwa/ $\mathrm{km}^{2}$. Kelurahan Nusukan Kecamatan Banjarsari merupakan salah satu wilayah utara Surakarta yang berbatasan dengan Kabupaten Karanganyar dan Kabupaten Boyolali, dengan jumlah penduduk 29.807 jiwa, 49,4\% laki-laki dan 50,6\% perempuan, terdapat 8.417 Kepala Keluarga (KK). Mayoritas mata pencaharian penduduk adalah buruh kurang lebih $30,77 \%$, tingkat pendidikan terbanyak lulus SLTA 34,5\%, dan mayoritas beragama Islam 90,86\% dan 62,4\% adalah usia produktif ( Laporan Monografi Dinamis Kelurahan Nusukan Kecamatan Banjarsari bulan Agustus 2016). Mengamati situasi dan kondisi warga Kelurahan Nusukan yang mayoritas berada pada golongan usia produktif $(62,4 \%)$ sudah semestinya kita berpikir positif bahkan tersenyum lega karena ini berkaitan dengan pendapatan yang diterima per Kepala Keluarga untuk memenuhi berbagai kebutuhan hidup sehari-harinya. Namun apabila dilihat dari prosentase mata pencahariannya $42,54 \%$ menengah ke bawah ( petani, buruh dan pedagang kecil dan menengah) sebesar maka ini berarti masih banyak penduduk dengan pendapatan minimal sampai tingkat UMR. Dengan tingkat kepadatan 
penduduk tertinggi di Jawa Tengah tentu berpotensi menimbulkan permasalahan dalam beberapa hal, misalnya produksi sampah yang melimpah dari aktivitas keseharian setiap kepala keluarga dan warga Nusukan. Menurut Laporan Monografi Dinamis Kelurahan Nusukan Kecamatan Banjarsari per Agustus 2016, setiap minggu produksi sampah dari berbagai aktivitas mencapai kurang lebih 5 ton atau $5000 \mathrm{~kg}$ per minggu, terdiri dari limbah organik dan limbah anorganik. Lalu kemana produksi limbah sebanyak itu akan dibuang, mampukah Tempat Pembuangan Akhir (TPA) ataupun Tempat Pembuangan Sampah (TPS) menampung produksi limbah sebanyak itu, barangkali untuk jangka pendek masih mampu menampung limbah tapi bagaimana jangka panjang nya nanti? Limbah organik barangkali tidak menimbulkan masalah besar dan serius penanganannya sepanjang terorganisir pembuangannya karena golongan limbah organik ini dapat membusuk, bagaimana dengan limbah anorganik yang sulit bahkan tidak dapat membusuk? Dari kapasitas limbah 5 ton atau $5.000 \mathrm{~kg}$ per minggu sebagian besar adalah jenis limbah anorganik yang tak bisa dimusnahkan bahkan berpotensi menimbulkan masalah serius serta menjadi sumber bencana. Limbah yang berasal dari plastik adalah ancaman besar dan sumber bencana jika tidak ditangani dengan benar dan serius.

Dampak negatif limbah padat yang bertumpuk dan tak dapat terurai dalam waktu lama akan mencemarkan tanah. Menurut Gelbert dkk (1996) ada tiga dampak negatif serius limbah terhadap kesehatan manusia, lingkungan dan keadaan sosial ekonomi. Pembuangan limbah yang tidak terkontrol merupakan area yang cocok bagi beberapa organisme dan menarik bagi berbagai binatang seperti lalat, kecoa, anjing dan lain-lain yang berpotensi menjangkitnya penyakit seperti kholera, diare, tifus, demam berdarah, jamur kulit dan sebagainya. Selain itu rembesan limbah yang masuk dalam saluran drainase atau sungai akan berdampak buruk bagi kualitas air dan menimbulkan bau busuk yang mencemari lingkungan. Pada akhirnya dampak tersebut berdampak pula terhadap kondisi sosial ekonomi, tingkat kesehatan masyarakat menurun menimbulkan pembiayaan kesehatan meningkat dan berdampak pada terganggunya ekosistem dan infrastruktur akibat timbunan limbah yang tidak terorganisir dengan baik. Suatu keharusan untuk memikirkan secara serius penanganan serta pemanfaatan limbah anorganik agar tidak menjadi ancaman dan sumber bencana bagi kehidupan kita. Sekaligus mencari peluang dari pemanfaatan limbah anorganik agar memiliki nilai lebih. Untuk itulah kami Tim Pengabdian Kepada Masyarakat tertarik dan tergerak untuk melakukan sesuatu melalui pemanfaatan limbah kantong plastik (tas kresek) menjadi aneka produk kerajinan bagi ibu-ibu PPK Kelurahan Nusukan Kecamatan Banjarsari Surakarta, sekaligus menjadi peluang usaha untuk menambah atau meningkatkan penghasilan keluarga melalui pemanfaatan limbah kantong plastik menjadi aneka produk kerajinan yang bernilai jual. 


\section{METODE}

Berawal dari survei dan pengamatan Tim Pelaksana Pengabdian Kepada Masyarakat setelah beberapa kali melakukan analisis situasi pada masyarakat khususnya pada Ibu-ibu PKK dan sekelompok pengrajin di Kelurahan Nusukan Kecamatan Banjarsari yang mengeluhkan banyaknya limbah kantong plastik dari aktivitas sehari-hari dan menginginkan adanya solusi penanganan yang tepat, bernilai guna dan bernilai ekonomis terhadap limbah kantong plastik tersebut, maka bentuk kegiatan Pengabdian Kepada Masyarakat ini adalah sebagai berikut :

\section{Presentasi}

Memberikan ceramah dan penyuluhan tentang bahaya limbah plastik (khususnya kantong plastik) apabila tidak dikelola dengan baik serta bagaimana mengubah limbah plastik yang membahayakan menjadi sesuatu yang bernilai guna dan bernilai ekonomis sebagai solusi penanganannya meskipun secara sederhana melalui sentuhan tangan Ibu-ibu PKK dan kelompok pengrajin.

\section{Peragaan dan Pembagian alat /bahan.}

Memperagakan dan memberikan pelatihan kepada Ibu-ibu PKK dan kelompok pengrajin melalui praktek/ demo bagaimana memanfaatkan kantong plastik yang selama ini biasa hanya digunakan sebagai kantong bungkus saat belanja barang-barang kebutuhan sehari-hari dan mengubah serta menyulapnya menjadi aneka produk kerajinan. Praktek/ demonstasi tentang bagaimana memanfaatkan kantong plastik yang selama ini biasa hanya digunakan sebagai kantong bungkus saat belanja barang-barang kebutuhan sehari-hari dan mengubah serta menyulapnya menjadi aneka produk kerajinan yang tidak hanya cantik dan indah tapi juga bernilai guna dan bernilai ekonomis melalui tangan kreatif dan inovatif Ibu-ibu PKK dan kelompok pengrajin. Kantong plastik aneka warna dilipat lalu digunting memanjang tidak terputus sehingga membentuk tali kecil panjang seperti benang, digulung selanjutnya dengan menggunakan alat sederhana berupa hak pen dengan teknik rajut ( crochet / knitting ) seperti merajut benang dengan berbagai variasi menjadi aneka produk kerajinan antara lain taplak meja tamu, taplak meja makan, alas telepon, tatakan (alas) piring makan dan gelas, cover /tutup saji, cover kulkas,box tissue, tas, dompet, bross maupun korsase, bandana, dan lain-lain.outcome yang diharapkan dari pelaksanaan kegiatan ini adalah membuka kesadaran Ibu-Ibu akan bahaya limbah kantong plastik bagi lingkungan, membudayakan kebersihan lingkungan, mengisi waktu dengan aktivitas positif dan bermanfaat dengan mengubah limbah plastik yang ada menjadi produk bernilai, mengembangkan kreativitas dan ketrampilan Ibu-ibu PKK dan kelompok pengrajin menghasilkan aneka produk kerajinan yang bernilai guna dan ekonomis untuk membantu meningkatkan pendapatan keluarga, mengembangkan eksistensi, mengasah ketrampilan dan ketajaman jiwa bisnis melalui keikutsertaan dalam beberapa even seperti pasar malam, bazar, pameran, expo dan lain-lain dalam skala lokal, regional, nasional hingga internasional. 


\section{HASIL PEMBAHASAN DAN DAMPAK}

\section{A. Teknik pemanfaatan limbah plastik menjadi aneka produk kerajinan}

Departemen Pekerjaan Umum sejak tahun 2008 menetapkan kebijakan dan menjalankan program pengelolaan limbah khususnya limbah anorganik dengan menerapkan konsep 3R. Solusi ini dijalankan dalam rangka pengurangan dan pengelolaan limbah anorganik khususnya limbah plastik. Konsep $3 \mathrm{R}$ tersebut adalah:

1. Re-Use ( penggunaan kembali sampah secara langsung baik untuk fungsi yang sama ataupun fungsi lain.

2. Reduce (pengurangan segala sesuatu yang menyebabkan timbunya sampah)

3. Recycle (mendaur ulang atau memanfaatkan kembali sampah setelah mengalami proses pengolahan.

Sebagaimana sudah sering kita dengar dan ketahui bahwa upaya pengurangan limbah plastik dilaksanakan secara serius. Ada beberapa konsep dan program yang dilaksanakan oleh Pemerintah negara kita misalnya diet kantong plastik. Banyaknya limbah plastik yang bisa mencapai beratus-ratus ton, membuat pemerhati lingkungan menetapkan Indonesia ke dalam darurat sampah plastik. Karena Indonesia merupakan negara penghasil limbah plastik terbesar kedua di dunia. Berangkat dari kenyataan tersebut pemerintah pun tergerak membuat program baru kantong plastik berbayar di seluruh ritel besar ataupun kecil, sebagai upaya mengurangi penggunaannya.

Pelaksanaan Program Re-Use ini adalah dengan menggunakan kembali limbah plastik untuk diubah atau dibuat menjadi barang lain yang mermanfaat. Program ini harus didukung dan dibekali tekad, keseriusan, ketekunan dan kreativitas beberapa kerajinan tangan yang bisa dibuat dengan memanfaatkan limbah kantong plastik dengan cara dirajut oleh Ibu-ibu PKK dan kelompok pengrajin sekaligus merupakan upaya untuk melestarikan budaya kerajinan tangan merajut ( crochet dan knitting) yang identik dengan budaya kerajinan tangan kaum wanita jaman dulu ( kerajinan tangan eyang putri-eyang putri ) jangan samapi punah menjadi sekedar warisan. Untuk mendukung program pengurangan limbah plastik, melakukan daur ulang kantong-kantong plastik yang ada di rumah kita juga bisa dilakukan oleh.setiap keluarga, Alih-alih membuang tumpukan kantong plastik yang udah terlanjur ada di rumah, kenapa tidak kita "sulap" saja kantong-kantong plastik itu jadi barang lucu dan indah yang bermanfaat, yang memiliki nilai guna dan nilai ekonomis seperti produk kerajinan sebagai nerikut:
a. Keranjang Sampah
b. Kotak tissue
c. Sandal kamar
d. Bandana, kalung dan gelang 

e. Taplak meja
f. Tatakan / alas piring dan gelas
g. Talakan / alas telepon
h. Tutup/Cover kulkas
i. Tas dan dompet
j. Topi n sepatu sandal
k. Pompom/ Bunga vas
1. Bross/ korsase

Pembuatan aneka produk kerajinan berbahan limbah plastik ( tas kresek) ini membutuhkan bahan utama tas kresek warna-warni yang disesuaikan kebutuhan dan jenis produk kerajinan yang dihasilkan nantinya. Misalnya untuk membuat bross/ korsase bunga diperlukan bahan tas kresek warna warni seperti merah, pink, kuning, orange, ungu dan putih, sedangkan daunnya diperlukan tas kresek warna hijau. Bahan-bahan yang sudah tersedia dipersiapkan untuk dibuat seperti benang yang akan dirajut. Alat-alat yang dipergunakan adalah gunting dan hak pen. Dengan cara dilipat rapi sisakan kkemudian dipotong-potong memanjang dengan jarak yang sama kurang lebih $0,5 \mathrm{~cm}$ sampai dengan $1 \mathrm{~cm}$ sisakan $3 \mathrm{~cm}$, tetapi jangan sampai putus. Sisa $3 \mathrm{~cm}$ tersebut berfungsi sebagai penyambung agar guntingan plastik memanjang tanpa terputus membentuk benang, lalu di gulung dan siap untuk digunakan merajut menjadi aneka produk kerajinan yang indah, cantik dan menarik serta bernilai seni dan bernilai ekonomis. Layak untuk dijual dan bisa menambah pendapatan keluarga bahkan dikembangkan sebagai usaha kreatif dimulai dari home industry hingga menjadi produk unggulan di pasaran.

\section{B. Pengemasan dan pemasaran produk kerajinan hasil pemanfaatan limbah kantong plastik}

Disamping bernilai guna Ibu-Ibu PKK dan kelompok pengrajin juga bisa meningkatkan nilai ekonomisnya dengan memasarkan produk kerajinan tersebut untuk membantu menambah pendapatan keluarga sekaligus mengurangi tumpukan limbah plastik di rumah. Dan tidak mustahil Ibu-ibu merasa tertantang untuk mengembangkan usaha ini lebih luas menjangkau pasar menengah ke atas. Dengan mengikuti berbagai even seperti bazar, pasar malam, pameran UKM, expo dan even sejenis lain agar bisa lebih mengmbangkan sayap ke pasar regional, nasional bahkan internasional. Aaneka produk kerajinan yang indah, cantik dan menarik serta bernilai seni dan bernilai ekonomis. Layak untuk dijual dan bisa menambah pendapatan keluarga bahkan dikembangkan sebagai usaha kreatif dimulai dari home industry hingga menjadi produk unggulan di pasaran.

\section{Dampak}

Peningkatan ketrampilan dan peningkatan kesejahteraan dapat dirasakan oleh keluarga dengan adanya tambahan pendapatan dengan menerapkan pelatihan pemanfaatan limbah plastik menjadianeka produk kerajinan ini dalam usaha rumahan (Home Industry) 


\section{KESIMPULAN DAN SARAN}

\section{A. Kesimpulan}

Berdasarkan analisis situasi, permasalahan yang ada pada sasaran (kelompok pengrajin dan ibu-ibu PKK) di Kelurahan Nusukan Kecamatan Banjarsari Kodia Surakarta serta hasil pelaksanaan berupa penyuluhan dan pelatihan tentang pemanfaatan limbah plastik ( tas kresek) menjadi aneka produk kerajinan, maka dapat disimpulkan :

1. Kelompok pengrajin dan Ibu-ibu PKK Kelurahan Nusukan Kecamatan Banjarsari Surakarta sangat antusias mengikuti penyuluhan tentang bahaya limbah plastik bagi lingkungan dan pelatihan pemanfaatan limbah plastik menjadi aneka produk kerajinan, dapat dilihat dari semangat mereka berlatih merajut dan banyaknya pertanyaan yang mereka ajukan serta kesungguhan mereka mencoba berbagai jenis rajutan berbahan tas kresek.

2. Kelompok pengrajin dan Ibu-ibu PKK Kelurahan Nusukan Kecamatan Banjarsari Surakarta sangat antusias mengikuti pelatihan dan berharap ada pendampingan dari Tim PKM STIE AUB Surakarta tentang pemasaran aneka produk kerajinan hasil pemanfaatan limbah plastik (tas kresek) ini.

\section{B. Saran}

1. Disarankan agar pada kegiatan Pengabdian Kepada Masyarakat berikutnya tidak hanya perwakilan setiap RW saja, tetapi setiap RT atau dasa wisma.

2. Disarankan pada kegiatan Pengabdian Kepada Masyarakat yang akan datang tidak hanya limbah tas kresek saja tetapi limbah plastik yang lain misal botol plastik dan limbah plastik lainnya.

3. Disarankan kegiatan Pengabdian Kepada Masyarakat ini tidak berhenti hanya sampai disini saja, tetapi ada tindak lanjut sehingga terjalin kerjasama yang berkesinambungan antara Tim Pengabdian Kepada Masyarakat dengan Kelompok Pengrajin dn Ibu-ibu PKK serta bisa merangkul para pengusaha besar sebagai sasaran pelaksana dan menjadi orang tua angkat bagi kelompok pengrajin kecil hingga menengah melalui program Corporate Social Responsibility (CSR).

4. Disarankan pengabdian yang akan datang dapat dikembangkan pada ide-ide kreatif dan inovatif lainnya.

\section{DAFTAR PUSTAKA}

http://www.g-excess.com/ pengertian dan jenis limbah plastik

http://pengelolaanlimbah wordpress.com

ilmulingkungan.com, limbah

kadekleo 13blogspot.com, artikel sampah plastik 
mustika karindra, Daripada sia-sia jadi limbah kantong plastikbisadiubah jadi 7 barang lucu, tianlibra blogspot.com>, Artikel limbah plastik Tian Galauest

www.wirasejati.com>wirausaha, , cara pengolahan limbah plastik yang ramah lingkungan

www.haiyul.fadhlitk/ dampak limbah plastik bagi lingkungan

${ }^{p}$ yulianalecture,chemistry.blogspot,com/ makalah pengolahan sampah 